\title{
PENERAPAN MODEL PEMBELAJARAN PROBLEM BASED LEARNING (PBL) SEBAGAI UPAYA MENINGKATAN HASIL BELAJAR FISIKA SISWA PADA MATERI HUKUM NEWTON
}

\author{
SETIONINGSIH \\ MAN 1 Pesawaran \\ E-mail :setioningsihmsc@gmail.com
}

\begin{abstract}
ABSTRAK
Penelitian ini bertujuan untuk mengetahui peningkatan hasil belajar siswa, aktivitas guru dan siswa, kemampuan guru dalam mengelola pembelajaran, serta respon siswa terhadap penerapan Model Pembelajaran Problem Based Learning (PBL) dalam proses pembelajaran. Jenis penelitian ini adalah Penelitian Tindakan Kelas (PTK). Subjek dalam penelitian ini adalah siswa-siswi kelas X MAN 1 Pesawaran tahun peajaran 2018/2019 dengan jumlah siswa 32 orang. Instrumen pengumpulan data yang digunakan dalam penelitian yaitu lembar observasi, tes dan angket yang ketiganya dianalisis dengan statistik deskriptif. Hasil penelitian menunjukkan bahwa (1) persentase ketuntasan individual secara keseluruhan meningkat dari siklus I sampai siklus III yaitu 69\%, 81\%, dan 94\%, dan persentase ketuntasan klasikal secara keseluruhan juga meningkat yaitu 50\%,60\%, dan $80 \%$. (2) adanya peningkatan aktivitas guru dan siswa selama proses pembelajaran. (3) terjadi peningkatan keterampilan guru dalam mengelola pembelajaran dari ketegori cukup baik menjadi baik. (4) respon siswa cenderung positif dimana $100 \%$ siswa menyatakan senang terhadap pembelajaran dengan menggunakan Model Pembelajaran Problem Based Learning (PBL) Berbasis Konstruktivisme ini. Dari penelitian ini dapat disimpulkan bahwa penerapan Model Pembelajaran Problem Based Learning (PBL) dapat meningkatkan hasil belajar fisika siswa kelas X MAN 1 Pesawaran pada materi Hukum Newton
\end{abstract}

Kata kunci: Problem Based Learning (PBL), Hasil Belajar

\section{PENDAHULUAN}

Peran pendidikan sangat penting untuk menciptakan kehidupan bangsa yang cerdas, damai, dan demokratis. Didalam kurikulum 2013 terdapat beberapa prinsip pembelajaran yang diharapkan menunjang mutu pendidikan. Diantara prinsip-prinsip pada kurikulum 2013 yaitu mendorong siswa menjadi peserta didik yang aktif, dimulai dengan siswa mengamati fenomena atau peristiwa tertentu sehingga guru dapat membangkitkan rasa ingin tahu siswa terhadap fenomena atau peristiwa tersebut. Pada kurikulum ini guru bertindak sebagai motivator dan fasilitator, namun pada akhir kegiatan inti guru memberikan penjelasan penyempurnaan dari kegiatan siswa. Menurut Jean Pieget pendidikan sebagai penghubung dua sisi, disatu sisi individu yang sedang tumbuh dan disisi lain nilai sosial, intelektual, dan moral yang menjadi tanggung jawab pendidik untuk mendorong individu tersebut (Sagala, 2011:1).

Dari observasi yang penulis lakukan di MAN 1 Pesawaran pada tanggal 23 Februari 2019, penulis menemukan bahwa masih banyak guru yang menggunakan pendekatan pembelajaran konvensional, yaitu siswa hanya memperoleh pengetahuan yang disampaikan oleh guru. Hal tersebut menyababkan hasil belajar siswa yang didapatkan kurang sesuai dengan yang diharapkan. Hasil belajar merupakan salah satu faktor yang ditentukan oleh proses belajar. Menurut Dimyati dan Mudjiono (2001:3-4), "hasil belajar merupakan hasil dari suatu interaksi tindak belajar dan mengajar. Dari sisi guru, tindak mengajar diakhiri dengan proses evaluasi hasil belajar. Dari sisi siswa, hasil belajar merupakan berakhirnya penggal dan puncak proses belajar". 
Menurut Ngalim (2016, dalam Suniana), "Peserta didik dikatakan tuntas apabila telah mencapai standar kriteria ketuntasan minimal. Pencapaian ketuntasan peserta didik di pengaruhi beberapa faktor pendukung dalam pembelajarannya, kurang lengkapnya faktor pendukung dalam pembelajaran akan menjadi kendala peserta didik mencapai ketuntasan". Nilai KKM untuk pelajaran fisika di kelas X IPA 1 di MAN 1 Pesawaran adalah 70. Namun ketika diberikan evaluasi, dari 32 siswa kelas X IPA1 hanya 6 orang yang nilainya mencapai nilai KKM atau hanya sekitar $19 \%$. Selebihnya tidak mencapai nilai KKM atau nilainya dibawah 70 .

Proses perolehan pengetahuan akan terjadi apabila guru dapat menciptakan suatu kondisi pembelajaran yang sesuai dengan karakteristik pembelajaran fisika. Pembelajaran yang demikian merupakan pembelajaran yang mengutamakan keaktifan siswa. Apabila guru berhasil menciptakan suasana yang dapat menyebabkan siswa termotivasi aktif dalam belajar, maka akan memungkinkan terjadi peningkatan hasil belajar. Guru harus menggunakan proses pembelajaran yang akan menggerakkan siswa menuju kemandirian, kehidupan yang lebih luas, dan belajar sepanjang hayat. Lingkungan belajar yang dibangun guru harus mendorong cara berfikir siswa sehingga siswa dapat dengan mudah untuk memahami pembelajaran.

Berdasarkan hal tersebut, perlu diupayakan pendekatan pembelajaran yang dapat meningkatkan pemahaman konsep fisika siswa, salah satu alternatif pendekatan pembelajaran yang dianggap dapat meningkatkan pemahaman konsep fisika siswa adalah pembelajaran berbasis konstruktivisme. Karena siswa aktif secara mental membangun pengetahuannya yang dilandasi struktur kognitif yang telah dimilikinya.

Metode ini erat kaitannya dengan pendekatan konstektual. Banyak ahli yang menyebutnya sebagai metode pembelajaran tetapi ada pula ahli yang menyebutnya sebagai model pembelajaran (Warsono dan Hariyanto, 2013:147). Pembelajaran berbasis masalah digunakan untuk merangsang berpikir tingkat tinggi dalam situasi berorientasi masalah, termasuk di dalamnya cara bagaimana peserta didik belajar. Model pembelajaran berdasarkan masalah merupakan suatu model pembelajaran yang didasarkan pada banyaknya permasalahan yang membutuhkan penyelidikan autentik yakni penyelidikan yang membutuhkan penyelesaian nyata dari permasalahan nyata (Trianto, 2010:90).

\section{METODE PENELITIAN}

Pada penelitian ini, penulis menggunakan pendekatan deskriptif. Yang sudah disesuaikan dengan tujuan pokok penelitian, yaitu untuk mengetahui peningkatan hasil belajar fisika dengan menggunakan model pembelajaran Problem Based Learning (PBL) pada materi hukum Newton. Jenis penelitian yang digunakan adalah Penelitian Tindakan Kelas (PTK), yang merupakan salah satu upaya yang dapat dilakukan guru untuk meningkatkan kualitas peran dan tanggung jawab guru khususnya dalam pengelolaan pembelajaran (Sanjaya, 2011:13). Adapun rancangan siklus pada penelitian tindakan kelas yang dilakukan dari awal hingga akhir dapat dilihat pada gambar berikut: 


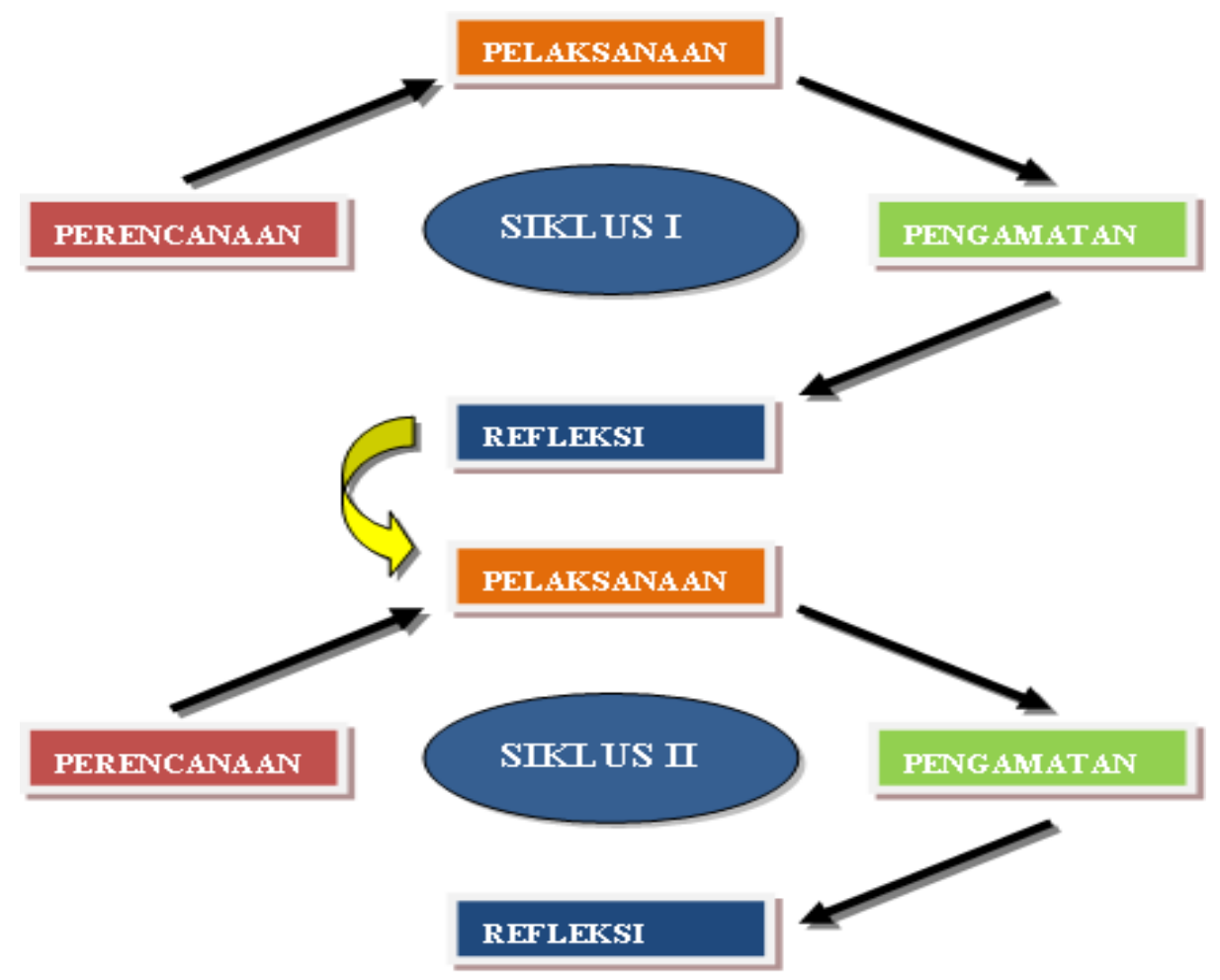

Gambar 1. Alur Penelitian PTK Model Kemmis and Taggart

Penelitian ini dilaksanakan di MAN 1 Pesawaran Lampung. Penelitian dilakukan pada tanggal 26 januari 2019 s/d 2 februari 2019 semester genap tahun ajaran 2018/2019. Subjek dalam penelitian ini adalah seluruh siswa-siswi kelas X IPA1 di MAN 1 Pesawaran sejumlah 32 siswa. Sedangkan objek dalam penelitian ini adalah hasil belajar fisika siswa kelas X IPA1. Data yang diambil berupa hasil belajar siswa, aktivitas guru dan siswa, kemampuan guru dalam mengelola pembelajaran, dan respon siswa terhadap model pembelajaran problem based learning (PBL). Instrumen yang digunakan dalam penelitian ini meliputi lembar test awal (pretest) dan test akhir (post-test), lembar pengamatan aktivitas guru, lembar pengamatan kemampuan guru mengelola pembelajaran dan lembar angket respon siswa. Teknik analisis data dalam penelitian ini menggunakan uji persentase dengan metode kuantitatif.

$P=\frac{f}{n} \times 100 \% \quad$ (Sudijono, 2005:43)

Dimana : $\mathrm{P}=$ persentase yang dicari

$\mathrm{f}=$ frekuensi siswa yang tuntas

$\mathrm{n}=$ jumlah siswa keseluruhan

Ketuntasan individual pada materi yang akan di tentukan tercapai apabila perolehan skor siswa mencapai nilai $\mathrm{KKM}$, yaitu $\geq 70$ atau dengan nilai konversi $\geq 2,66$, sedangkan ketuntasan klasikal tercapai apabila $75 \%$ siswa lulus KKM. Aktivitas guru dan siswa dikatakan baik apabila memperoleh hasil sekurang-kurangnya $75 \%$. Sebaliknya apabila hasil yang di peroleh di bawah $75 \%$ maka aktivitas guru dan siswa dikatakan kurang atau tidak baik. Hal ini sesuai dengan pendapat Mulyasa (2012:183) yang mengatakan bahwa, "Suatu pembelajaran dikatakan berhasil apabila sekurang-kurangnya 75\% dari jumlah siswa termotivasi belajar menggunakan media pembelajaran”.

Analisis data respon siswa terhadap pembelajaran dengan menggunakan model pembelajaran problem based learning (PBL) dengan menggunakan angket respon siswa. Tanggapan siswa 
dikatakan baik apabila memperoleh hasil sekurang-kurangnya $75 \%$. Sebaliknya apabila hasil yang di peroleh dibawah 75\% maka tanggapan siswa dikatakan kurang atau tidak baik.

\section{HASIL PENELITIAN DAN PEMBAHASAN}

Data hasil penelitian yang diperoleh dari MAN 1 Pesawaran tahun ajaran 2018/2019 selama tiga siklus dan pada setiap siklus diamati oleh dua orang pengamat. Analisis penelitian dilakukan dengan mendeskripsikan gambaran terhadap tes awal dan akhir siswa (pre-test dan post-test), gambaran terhadap aktivitas guru dan siswa, gambaran pengelolaan kelas guru, dan gambaran respon siswa terhadap pembelajaran dengan menggunakan model pembelajaran Problem Based Learning (PBL) pada materi hukum newton.

\section{Siklus I}

Berdasakan hasil post-test pada siklus I terlihat bahwa dari 32 orang siswa terdapat 22 siswa yang tuntas secara individual atau dengan kata lain ketuntasan individual secara keseluruhan pada siklus I adalah sebesar 69\%, sedangkan ketuntasan klasikal secara keseluruhan yaitu sebesar $50 \%$ dimana dari 10 soal terdapat 5 soal yang belum tuntas secara klasikal. Aktivitas guru selama proses pembelajaran menggunakan model pembelajaran Problem Based Learning (PBL) pada siklus I adalah 65\% dan dikategori cukup baik. Sedangkan, aktivitas siswa selama proses pembelajaran pada siklus I adalah $60 \%$ dan dikategorikan cukup baik.

Kemampuan guru dalam mengelola pembelajaran menggunakan model pembelajaran Problem Based Learning (PBL) terdiri dari empat bagian yaitu pendahuluan (kegiatan awal), kegiatan inti, penutup (kegiatan akhir), dan pengamatan suasana kelas. Dimana secara keseluruhan kemampuan guru dalam mengelola pembelajaran menggunakan model pembelajaran Problem Based Learning (PBL) pada siklus I ini dapat dikategorikan cukup baik dengan perolehan skor rata-rata sebesar 2,59. Kelemahan dan hambatan dalam pelaksanaan proses pembelajaran pada siklus I adalah sebagai berikut:

a. Berdasarkan hasil posttest, terdapat 5 siswa yang hasil belajarnya belum tuntas secara individual dan terdapat 5 soal yang belum tuntas secara klasikal. Hal ini dikarenakan masih kurangnya keterampilan guru dalam memberikan penguatan materi dan belum maksimal memberi contoh soal yang relevan dengan materi pembelajaran.

b. Berdasarkan hasil penilaian aktivitas guru dan siswa, terdapat beberapa aktivitas guru dan siswa yang masih kurang dan perlu perbaikan.

Berdasarkan hasil keterampilan guru dalam mengelola pembelajaran, terdapat beberapa keterampilan guru yang masih kurang diantaranya adalah: ketika memberi informasi tentang materi yang akan dipelajari, ketika membagi siswa kedalam kelompok, mendemonstrasikan materi sesuai LKS, memberi kesempatan siswa untuk berfikir, memecahkan masalah dan berdiskusi, ketika membimbing siswa dalam berdiskusi, ketika memberi penguatan materi dan membimbing siswa membuat kesimpulan, kurangnya keterampilan guru dalam mengajak siswa aktif dan antusias dalam pembelajaran serta ketika mengkondisikan pembelajaran berpusat pada siswa.

\section{Siklus II}

Berdasakan hasil post-test pada siklus II terlihat bahwa dari 32 orang siswa terdapat 26 siswa yang tuntas secara individual atau dengan kata lain ketuntasan individual secara keseluruhan pada siklus II adalah sebesar $81 \%$. Sedangkan ketuntasan klasikal secara keseluruhan yaitu sebesar $60 \%$ dimana dari 10 soal terdapat 4 soal yang belum tuntas secara klasikal. 
Aktivitas guru selama proses pembelajaran menggunakan model pembelajaran Problem Based Learning (PBL) pada siklus II adalah 76\%. Sedangkan, aktivitas siswa selama proses pembelajaran pada siklus II adalah $70 \%$. Hasil penilaian kemampuan guru dalam mengelola pembelajaran menggunakan model pembelajaran Problem Based Learning (PBL) sudah lebih baik baik dari siklus I. Dimana secara keseluruhan kemampuan guru dalam mengelola pembelajaran menggunakan model pembelajaran Problem Based Learning (PBL) pada siklus II ini dapat dikategorikan baik dengan perolehan skor rata-rata sebesar 3. Selain itu, guru masih belum terampil dalam mengajak siswa aktif dan antusias dalam pembelajaran sehingga siswa masih belum terlibat langsung dalam proses pembelajaran.

\section{Siklus III}

Guru telah berhasil membimbing siswa dalam melaksanakan pembelajaran dengan menggunakan model pembelajaran Problem Based Learning (PBL) hingga dapat meningkatkan pemahaman siswa terhadap materi yang dipelajari. Hal ini dapat dilihat dari meningkatnya ketuntasan belajar siswa baik secara individual maupun secara klasikal, dimana pada siklus III ini hanya terdapat 1 siswa yang belum tuntas secara individual dan 2 soal yang belum tuntas secara klasikal.

Guru dan siswa juga lebih berhasil menyesuaikan aktivitas selama proses pembelajaran. Keterampilan guru dalam mengelola pembelajaran menjadi lebih baik di bandingkan dengan siklus sebelumnya, dimana terlihat adanya peningkatan skor keterampilan guru yang di siklus I sampai siklus III. Hal ini berarti bahwa guru telah berhasil menyajikan pembelajaran sesuai dengan kriteria yang diharapkan. Guru sudah mampu memantau kerja siswa, mulai pada saat berdiskusi dalam kelompok, hingga posttest dan berhasil membuat siswa antusias dalam belajar.

Berdasarkan hasil pada siklus III, maka tindakan dalam siklus diberhentikan karena hasil belajar sudah maksimal dan sebagian besar siswa telah berhasil menuntaskan belajarnya baik secara individual maupun secara klasikal, serta guru telah mampu menerapkan pembelajaran menggunakan model pembelajaran Problem Based Learning (PBL) dengan sangat baik. Berdasarkan hasil penelitian, maka dapat dilihat bahwa terjadi peningkatan dalam hasil belajar siswa dari tes awal (pre-test) yang dilakukan sebelum penerapan model pembelajaran problem based learning (PBL) hingga tes akhir (posttest) dilakukan setelah pembelajaran dengan menggunakan model pembelajaran problem based learning (PBL).

Hasil penelitian menunjukkan bahwa nilai ketuntasan rata-rata individual meningkat dari siklus I sampai dengan siklus III. Peningkatan hasil belajar disajikan pada Grafik 4.1 berikut:

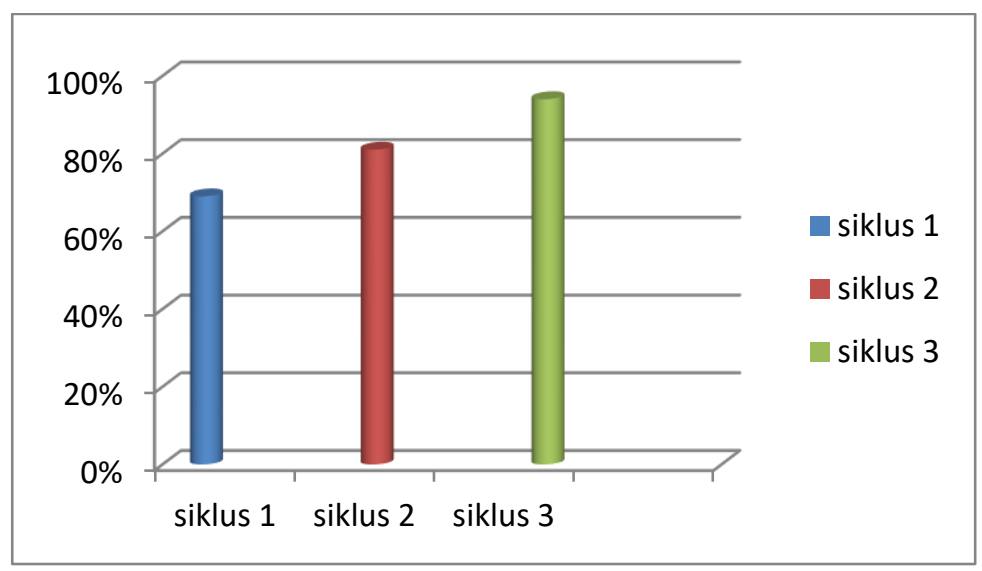

Gambar 2. Persentase Ketuntasan Individual 
Berdasarkan Grafik 2 dapat dijelaskan bahwa, adanya peningkatan persentase ketuntasan individual secara keseluruhan antara siklus I, II dan III. Pada siklus I persentase ketuntasan individual secara keseluruhan yaitu 69\%, artinya dari 32 siswa terdapat 22 siswa yang telah tuntas secara individual. Pada siklus II ketuntasan individual secara keseluruhan meningkat menjadi $81 \%$, artinya dari 32 siswa terdapat 26 siswa yang telah tuntas secara individual. Pada siklus III ketuntasan individual secara keseluruhan meningkat lagi menjadi 94\%, artinya dari 32 siswa terdapat 30 siswa yang telah tuntas secara individual. Selain ketuntasan individual, penelitian ini juga menunjukkan peningkatan dalam hasil ketuntasan klasikal secara keseluruhan dari siklus I hingga siklus III dengan menggunakan model pembelajaran problem based learning (PBL).

Peningkatan ketuntasan secara klasikal disajikan pada Grafik 3 berikut:

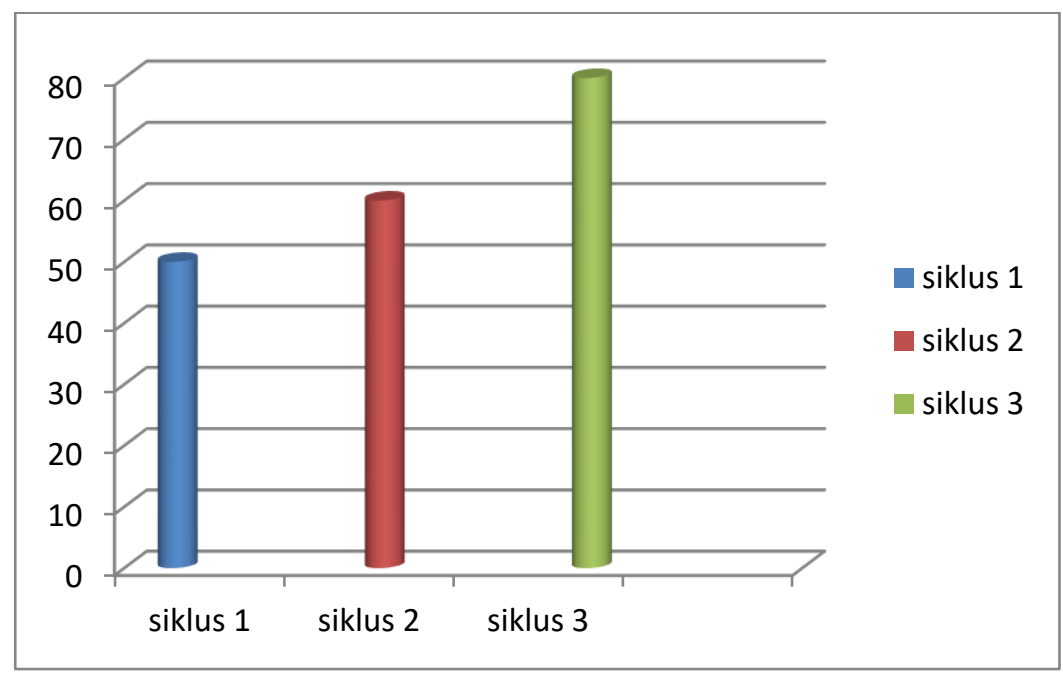

\section{Gambar 3. Persentase Ketuntasan Klasikal}

Berdasarkan Grafik 3 di atas terlihat bahwa adanya peningkatan ketuntasan klasikal secara keseluruhan dari siklus I sampai dengan siklus I. Pada siklus I persentase ketuntasan klasikal secara keseluruhan hanya mencapai $50 \%$, dimana dari 10 soal terdapat 5 soal yang belum tuntas secara klasikal. Pada siklus II persentase ketuntasan klasikal secara keseluruhan meningkat menjadi $60 \%$ dimana dari 10 soal terdapat 4 soal yang belum tuntas secara klasikal. Pada siklus III persentase ketuntasan klasikal secara keseluruhan meningkat lagi menjadi $80 \%$, dengan kata lain dari 10 soal hanya terdapat 2 soal yang belum tuntas secara klasikal.

Berdasarkan peningkatan ketuntasan individual dan klasikal yang diperoleh setelah pembelajaran selama 3 siklus, maka dapat disimpulkan bahwa penerapan model pembelajaran problem based learning (PBL) ini telah berhasil membantu siswa dalam memahami materi hukum Newton. Aktivitas guru dan siswa selama proses pembelajaran menggunakan model pembelajaran problem based learning (PBL) mengalami peningkatan pada setiap siklusnya. Hal ini dapat dilihat pada grafik dibawah ini: 


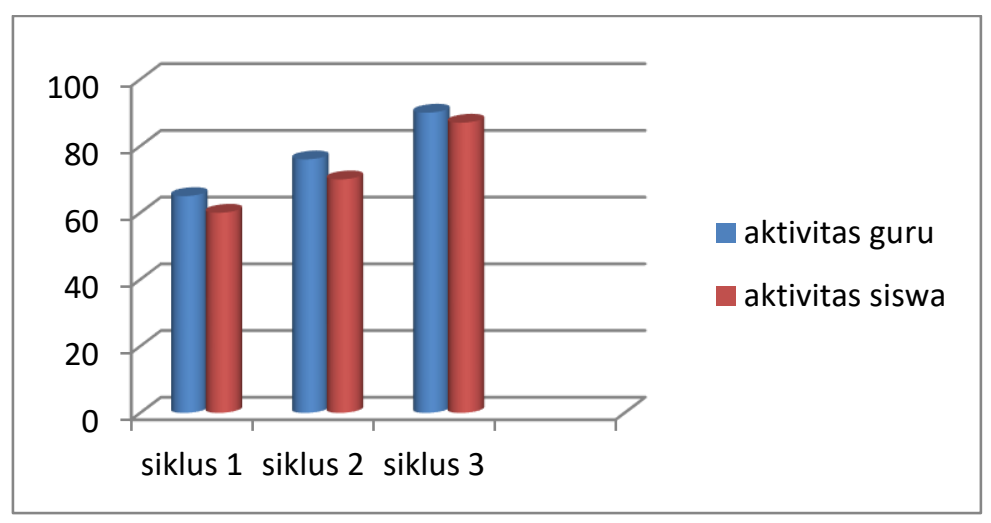

\section{Gambar 4 Persentase Aktivitas Guru dan Siswa}

Grafik 4 menjelaskan pada siklus I, aktivitas guru hanya memperoleh persentase $65 \%$, sedangkan aktivitas siswa hanya memperoleh $60 \%$. Pada Siklus I guru masih belum mampu mengelola kelas dengan baik sehingga proses pembelajaran menggunakan model pembelajaran problem based learning (PBL) belum berjalan maksimal. Pada siklus II terjadi peningkatan, sehingga persentase aktivitas guru diperoleh $76 \%$, sedangkan persentase aktivitas siswa diperoleh $70 \%$. Hal ini membuktikan bahwa guru semakin baik dalam mengelola pembelajaran menggunakan model pembelajaran problem based learning (PBL) dan siswa mulai serius dalam mengikuti pembelajaran.

Meskipun begitu, masih terdapat kekurangan salah satunya dalam mendemonstrasikan materi yang sesuai dengan LKS. Pada siklus III aktivitas guru dalam pelaksanaan pembelajaran menggunakan model pembelajaran problem based learning (PBL) mengalami peningkatan sehingga persentasenya menjadi $90 \%$ dan aktivitas siswa menjadi $87 \%$. Hal ini menunjukkan bahwa guru semakin terampil dalam mengelola kelas sehingga berdampak positif dalam proses pembelajaran.

Berdasarkan hasil penelitian dan analisis data, terlihat adanya peningkatan keterampilan guru dalam mengelola pembelajaran dengan penerapan model pembelajaran problem based learning (PBL). Secara rinci diperlihatkan pada grafik berikut:

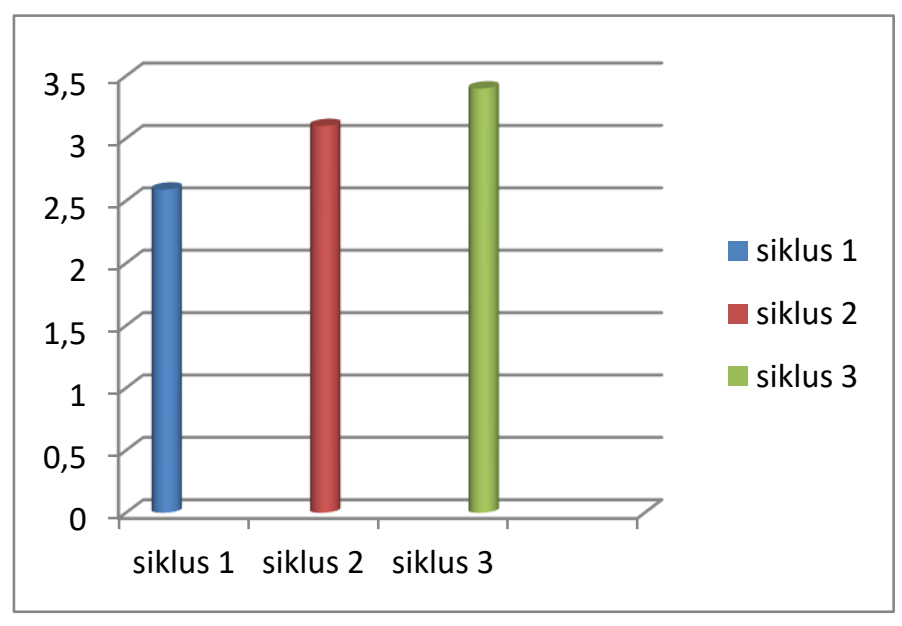

Gambar 5 Kemampuan Guru dalam Mengelola Pembelajaran

Gambar 5 menunjukkan adanya peningkatan keterampilan guru dalam mengelola pembelajaran dengan menerapkan model pembelajaran problem based learning (PBL) berbasis konstruktivisme dari siklus I hingga siklus III. Pada siklus I skor rata-rata yang dicapai oleh guru adalah 2,59 dengan kategori cukup baik, pada siklus II skor ratarata yang dicapai guru adalah 3,1 dengan kategori baik dan pada siklus III skor rata-rata yang dicapai guru adalah 3,4 dengan kategori baik. 
Dari grafik tersebut terlihat bahwa guru semakin terampil dalam mengelola pembelajaran dengan menggunakan model pembelajaran problem based learning (PBL). Dari penjelasan diatas terlihat adanya peningkatan dari siklus I sampai siklus III, baik peningkatan ketuntasan individual dan klasikal, peningkatan pada aktivitas guru dan peserta didik, dan peningkatan kemampuan guru dalam mengelola pembelajaran.

Jadi dapat disimpulkan bahwa penerapan modelpembelajaran problem based learning (PBL) berhasil membuat siswa tertarik dan semangat mengikuti pembelajaran. Selain itu respon siswa terhadap penerapan model pembelajaran problem based learning (PBL) juga cenderung positif. Tanggapan positif ini menunjukan bahwa siswa antusias dengan pembelajaran yang disajikan. Hal ini dapat memotivasi siswa untuk meningkatkan perhatian dan membuat mereka terlibat aktif dalam pengalaman pembelajaran yang menyenangkan dan bermakna. Motivasi ini mendorong siswa untuk melakukan aktivitas pembelajaran seperti yang teramati oleh pengamat. Tingginya respon siswa secara tidak langsung dapat membantu siswa mendapatkan pemahaman konsep yang utuh.

\section{KESIMPULAN}

Berdasarkan hasil penelitian dan analisis data pada penelitian tindakan kelas (PTK) yang telah dilaksanakan selama 3 siklus terlihat adanya peningkatan hasil belajar, aktivitas guru dan siswa, kemampuan guru dalam mengelola pembelajaran, dan respon siswa yang baik terhadap penerapan model pembelajaran problem based learning (PBL).

\section{DAFTAR PUSTAKA}

Dimyati dan Mudjiono. (2010). Belajar dan Pembelajaran. Jakarta: Rineka Cipta.

Mulyasa, Enco. (2012). Menjadi Guru Profesional Menciptakan Pembelajaran Kreatif dan Menyenangkan. Bandung: PT Remaja Rosda Karya.

Sagala, Syaiful. (2011). Konsep dan Makna Pembelajaran untuk Membantu Memecahkan Problematika Belajar dan Mengajar. Bandung

Alfabeta Sanjaya, Wina. (2011). Penelitian Tindakan Kelas. Jakarta: Kencana Prenada Media Group.

Sudijono, Anas. (2005). Pengantar Statistik Pendidikan. Jakarta : Rajawali Pers.

Suniana. (2016). Penerapan Pendekatan Pengajaran Terbalik (Reciprocal Teaching) untuk Meningkatkan Hasil Belajar Fisika Siswa pada Materi Fluida Statis di Kelas XI-IPA 1 SMA

Negeri 1 Bubon. Skripsi tidak di terbitkan. Darussalam: Universitas Syiah Kuala.

Suprijono, Agus. (2012). Cooperative Learning Teori dan Aplikasi PAIKEM. Yogyakarta: Pustaka Pelajar.

Trianto. (2010). Mendesain Model Pembelajaran Inovatif-Progresif: Konsep, Landasan, dan Implementasinya pada Kurikulum Tingkat Satuan Pendidikan (KTSP).Jakarta: Kencana Prenada Media Group.

Warsono dan Hariyanto. (2013). Pembelajaran Aktif Teori dan Asesmen. Bandung: PT. Remaja Rodakarya.

Parasamya, Wahyuni. (2017). Upaya peningkatan hasil belajar fisika siswa melalui penerapan model pembelajaran Problem Based Learning (PBL): Jurnal Ilmiah Mahasiswa (JIM) Pendidikan Fisika. Vol. 2 No.1 Januari 2017, 42-49 